\title{
Socio-demographic Characteristics as Determinants of Family Dynamics and Engagement in the Palayamanan System Approach among Agtas in Bicol
}

\section{Características sociodemográficas como determinantes de la dinámica familiar y del compromiso con el enfoque del sistema palayamanan entre los agtas de Bicol}

DOI: $10.46932 / s f j d v 2 n 4-044$

Received in: May 1st, 2021

Accepted in: Jun 30th, 2021

\author{
Jailyn N. Puerto \\ $\mathrm{MSc}$ \\ Philippine Rice Research Institute - Los Baños, Los Baños, Laguna \\ E-mail: jailynpuerto@gmail.com \\ Prof. Marison R. Dy \\ $\mathrm{PhD}$ \\ University of the Philippines Los Baños, Los Baños, Laguna \\ E-mail: mrdy@up.edu.ph \\ Jacqueline Lee O. Canilao \\ $\mathrm{MM}$ \\ Philippine Rice Research Institute - Los Baños, Los Baños, Laguna \\ E-mail: jleeo.canilao@gmail.com \\ Prof. Melissa P. Ferido \\ MSc \\ University of the Philippines Los Baños, UPLB, Los Baños, Laguna \\ E-mail: mpferido@gmail.com

\section{Prof. Benjamina Paula G. Flor \\ $\mathrm{PhD}$} \\ University of the Philippines Los Baños, UPLB, Los Baños, Laguna \\ E-mail: bpgflor@devcom.edu.ph
}

\begin{abstract}
Agtas are one of the Indigenous Peoples (IPs) residing in the mountainous parts of Luzon and some can be found in the Bicol Region. They are still dependent on agriculture in order to generate income and sustain their basic needs. Agta farming families are said to be already engaging in the Palayamanan System Approach (PSA), but their knowledge and skills still need to be enhanced to fully maximize the benefits that they can gain from the said approach. The study aimed to analyze the family dynamics structure among farming family systems of Agta Indigenous Peoples in Bicol. It also evaluated how family dynamics affect farm decision-making among Agta farming households. The family dynamics of the Agta farming families was assessed through the FACES IV (Olson, 2011). Results showed that there was unbalanced cohesion and unbalanced adaptability levels within the family system. On the other hand, communication and satisfaction were high. Gender and educational attainment showed a strong correlation to family cohesion and engagement in the PSA, respectively, therefore, both factors could be considered for effective development interventions to take place. Overall, the Agta communities' geographical condition, culture and beliefs, sources of information have affected their way of living, farm
\end{abstract}


practices, and farm-decision making. There have been very limited studies regarding indigenous people and communities in the Philippines. Thus, this study would serve as an entry point to further understand them and would guide in the formulation of appropriate strategies that will help improve and enhance their lives.

Keywords: Family dynamics, family system, Palayamanan System Approach, farm decision-making, Indigenous Peoples

\section{RESUMEN}

Los agtas son uno de los pueblos indígenas (PI) que residen en las zonas montañosas de Luzón y algunos se encuentran en la región de Bicol. Siguen dependiendo de la agricultura para generar ingresos y satisfacer sus necesidades básicas. Se dice que las familias agricultoras de Agta ya participan en el enfoque del sistema Palayamanan (PSA), pero sus conocimientos y habilidades aún deben mejorarse para maximizar los beneficios que pueden obtener de dicho enfoque. El estudio tenía como objetivo analizar la estructura de la dinámica familiar entre los sistemas familiares agrícolas de los pueblos indígenas Agta en Bicol. También se evaluó cómo la dinámica familiar afecta a la toma de decisiones agrícolas entre los hogares agrícolas Agta. La dinámica familiar de las familias agrícolas Agta se evaluó a través del FACES IV (Olson, 2011). Los resultados mostraron que había una cohesión desequilibrada y niveles de adaptabilidad desequilibrados dentro del sistema familiar. Por otro lado, la comunicación y la satisfacción eran altas. El género y el nivel educativo mostraron una fuerte correlación con la cohesión familiar y el compromiso con el APS, respectivamente, por lo tanto, ambos factores podrían ser considerados para que las intervenciones de desarrollo sean efectivas. En general, la condición geográfica, la cultura y las creencias de las comunidades Agta, así como las fuentes de información, han afectado a su modo de vida, a sus prácticas agrícolas y a la toma de decisiones agrícolas. Los estudios sobre los pueblos y comunidades indígenas en Filipinas son muy limitados. Por lo tanto, este estudio servirá como punto de entrada para comprenderlos mejor y guiará en la formulación de estrategias apropiadas que ayudarán a mejorar y potenciar sus vidas.

Palabras clave: Dinámica familiar, sistema familiar, enfoque del sistema Palayamanan, toma de decisiones agrícolas, pueblos indígenas.

\section{INTRODUCTION}

Agtas are one of the Indigenous Peoples (IPs) residing in the isolated mountainous parts of the island of Luzon, Philippines. Some of the Agta IPs can be found in the Bicol Region. In the early years, the Agta kinship was close-knit. Based on their family division of roles, the father and the elder sons usually hunt, while the mothers and daughters are left behind for the household chores. Though some Agta IPs still engage in traditional lifestyle, many of them have been influenced by modernization. Having adapted to the mainstream culture, much of their indigenous traditions are mere memories, no longer determining their way of life (PhilRice Los Baños, 2015). Majority of the Agta IPs still depend on agriculture to provide for their family. However, they have limited access to agricultural information and technologies since they live in areas that are not easily reached by developmental interventions despite improvement in the road accessibility of their locality. 
The Palayamanan System Approach (PSA) is best applied to small-scale rice farming environments where the potential income of a household is maximized through diversifying their crops and through other sources of income (i.e., fishpond, poultry and livestock). Some of the Agta farming families in Bicol may have engaged in this system for a long period of time for them to survive, thus, the benefits of sustaining this practice cannot be overemphasized. As we all know, close familial ties are characteristic of most Filipino families, but the Agta farmers said that it is perseverance to provide for their families that push them to continue being farmers (PhilRice Los Baños, 2015). The National Commission on Indigenous Peoples (NCIP) plays an important role in the IPs and Indigenous communities in the Philippines (PhilRice Los Baños, 2015). NCIP is an agency of the national government of the Philippines that protects and promotes the interest and well-being of the IPs and indigenous communities with due regard to their beliefs, customs, and institutions. In collaboration with both NCIP and PhilRice Los Baños, a study which can help the IPs improve their lives could be achieved. There have been very limited studies regarding IP families and communities in the Philippines. Thus, exploring their family dynamics would be an entry point to know and understand the IPs for further formulation of strategies that will help improve and enhance their lives. This study will analyze the family dynamics structure among farming family systems of Agta IPs in Bicol and evaluate how family dynamics affect farm decision-making among Agta farming households.

\subsection{THE AGTA IPS FARMING FAMILIES OF BICOL}

The Bicol Region comprises six provinces with an estimated IP population of 185,488 - ethnically composed of Agta, Agta-Tabangnon, Agta-Cimarron, and Abian or Kabihug indigenous groups. As years passed, the Agta indigenous communities have moved on from being isolated, small groups, and loosely structured socially to integrated members of complex societies with equally complex technologies (PhilRice Los Baños, 2016). Some outcomes from the historical experience of IPs have led to the issue of identity confusion, as they struggled for recognition within the context of mainstream society. This further made them feel inferior as they sensed that the society was unwelcoming of their kind, even until today. However, not all roots of social disruption grew from social discrimination. Introduction of agricultural inputs like fertilizers and pesticides changed the farming system of the Agta in Barangay Danao, Polangui, Albay from subsistence to commercial farming. These Agta indigenous communities all deserve attention because they continue to make a living only from agriculture. 


\subsection{FAMILY DYNAMICS}

Family dynamics is defined as the patterns of relating, or interactions, between family members (Strong bond, 2009). According to Olson, Gorall and Tiesel (2007), it involves four components such as: cohesion, flexibility/adaptability, communication, and satisfaction. Based on the FACES IV, these components have their distinct definitions as defined by Olson. Family cohesion refers to the emotional bonding that family members have toward one another. Family adaptability/flexibility refers to the ability of the family members to change or be changed in order to fit or work better in some situation or for some purpose. Moreover, family communication refers to the way verbal and non-verbal information is exchanged between family members. On the other hand, family satisfaction refers to the act of fulfilling a need, desire, or appetite, or the feeling gained from such fulfillment of family members.

\subsection{FAMILY ADAPTABILITY AND COHESION SCALE IV (FACES IV) AND THE CIRCUMPLEX} MODEL

The Family Adaptability and Cohesion Scale IV (FACES IV) is the latest version of the family self-report assessment designed to assess family cohesion and flexibility, which are the two central dimensions of the Circumplex Model of Marital and Family Systems (Olson, Gorall and Tiesel, 2007). Previous self-report assessments include three versions of the self-report measures which were FACES I, FACES II, FACES III and the observational assessment called the Clinical Rating Scale (CRS). The FACES IV was developed to tap the full continuum of the cohesion and flexibility dimensions from the Circumplex Model of Marital and Family Systems. There were six scales developed, with two balanced scales and four unbalanced scales designed to tap low \& high cohesion (disengaged and enmeshed) and flexibility (rigid and chaotic) (Olson, 2011a). Concurrent and discriminant validity was established, and new ratio scores measure the balanced and unbalanced levels of cohesion and flexibility.

\subsection{FARMING DECISIONS WITHIN AGRICULTURAL FAMILIES}

Decision-making within agricultural families is said to be varied and affected by different factors/. There are some instances that not only the farmer himself is taking control of the decisions within the family, but other members of the family are said to be also involved in the decision-making process. According to Nguyen et al. (2016), humans generally adapt to the natural world through the learning process in which they interpret their sensory impressions to give meaning to their environment and act accordingly. A study by Solano et al. (2001) showed that there are different factors that can affect the decision-making of farming families. The level of dedication to farming, the educational level and the 
size of the farm were the characteristics considered to be more strongly influencing the decision-making approaches.

\subsection{THE PALAYAMANAN SYSTEM APPROACH: ITS BENEFITS AND IMPACTS}

The term "Palayamanan" is a merger of the words "palay" (rice) and "kayamanan" (wealth), which exemplifies the goal to generate wealth through the cultivation of rice and other foods. Many farmers now agree that Palayamanan would be "the most practical way to achieve higher income especially in a calamity-prone area" (PhilRice, 2016, page 9). Therefore, it helps to improve the production efficiency of the farmer through the introduction of yield-increasing and cost-reducing technologies.

\section{METHODOLOGY}

A mixed method approach was used for the research conducted. The quantitative approach was used for generating the following data from the respondents: a. socio-demographic characteristics, $b$. family dynamics (levels of cohesion, flexibility, communication, and satisfaction), and c. engagement to Palayamanan System Approach and decision making on agricultural technology adaptation, On the other hand, the qualitative approach through informal interviews and observations were used to also support the data gathered. Respondents from the site were chosen through complete enumeration $(\mathrm{N}=74)$ with the following criteria: a.) respondents should be both Agta IPs, b.) a couple with children, c.) with at least one of them engaging in farm decision-making and activities, and d.) with rice farms. Moreover, the study locale is Bicol, specifically at Barangay Danao, Polangui, Albay. Survey questionnaires and The Family Adaptability and Cohesion Scale IV (FACES IV) tool by David Olson (2011) were used. The survey questionnaires were formulated in relation to the Palayamanan System Approach and Adaptation of Agricultural Technologies which also involves the information and technology transfer within the locality. On the other hand, The Family Adaptability and Cohesion Scale IV (FACES IV) by David Olson served as a tool in assessing the family dynamics of Agta farming families. The data gathering process included legal ethical guidelines like the principle of "free, prior, and informed consent". This is protected by the United Nations' Universal Rights of Indigenous Peoples and embodied in the NCIP Administrative Order No. 1. Thus, there have been community conferences made for the introduction of the study, its proponents, objectives, limitations, and expected outputs for their approval. Furthermore, the data were checked and encoded for analysis. Data from secondary sources were used to support primary data. Quantitative and qualitative data were analyzed through descriptive statistics using Statistical Packages for the Social Sciences (SPSS) version 20.0 and a statistical analysis using STATA software was done by INSTAT-UPLB in Los Baños, Laguna. To assess the relationships among variables such as the socio- 
demographic characteristics, family dynamics, farm-decision making to PSA and agricultural technologies adaptation, the following were used with the specified indicators:

Cramer's V Correlation Coefficient

$$
\begin{aligned}
& \mathrm{V}=<0.10 \quad \text { weak association } \\
& \mathrm{V}=0.10-0.30 \quad \text { moderate association } \\
& \mathrm{V}=>0.30 \quad \text { strong correlation }
\end{aligned}
$$

Spearman's Rho Correlation

$$
\begin{aligned}
& \mathrm{Rs}=<0.20 \quad \text { very weak association } \\
& \mathrm{Rs}=0.21-0.40 \quad \text { weak association } \\
& \mathrm{Rs}=0.41-0.60 \quad \text { moderate association } \\
& \mathrm{Rs}=0.61-0.80 \quad \text { strong association } \\
& \mathrm{Rs}=0.81-1.00 \quad \text { very strong association }
\end{aligned}
$$

Point Biserial (Pbis) Correlation Coefficient

$$
\begin{array}{ll}
\text { Coef. }=<0.20 & \text { very weak correlation } \\
\text { Coef. }=0.21-0.40 & \text { weak correlation } \\
\text { Coef. }=0.41-0.60 & \text { moderate correlation } \\
\text { Coef. }=0.61-0.80 & \text { strong correlation } \\
\text { Coef. }=0.81-1.00 & \text { very strong correlation }
\end{array}
$$

\section{RESULT AND DISCUSSION}

\subsection{SOCIO-DEMOGRAPHIC CHARACTERISTICS OF THE RESPONDENTS}

Table 1 shows that $54.1 \%$ out of the 74 respondents from the Agta farming families were female. Majority of them attended elementary schooling. Moreover, most of the respondents (32.4\%) were 40-49 years of age and majority also were married couples $(86.5 \%)$. There were $2.7 \%$ of the respondents with single status due to the non-availability of the other partner; the considered respondents then were the eldest child of the couple. According to the Philippine Statistics Authority (2015), Bicol Region's per capita poverty threshold in 2015 was placed at Php21,476. Based on the data analyzed (Table 1), 54.0\% of the Agta farming families have less than or equal to the annual family gross income of Php25,000; thus, are considered poor. This reflects that Bicolano families with five members would at least need Php8,948 average monthly income to meet their needs, both basic food and nonfood. Majority of the Agta farming families, with $32.4 \%$ of the respondents interviewed, have a large household size of 11 and above. This 
shows that an extended family system, which included the grandparents, aunts, uncles, and other relatives, is still practiced within the Agta community.

Table 1. Socio-demographic Characteristics of Agta Farming Families in Danao, Polangui

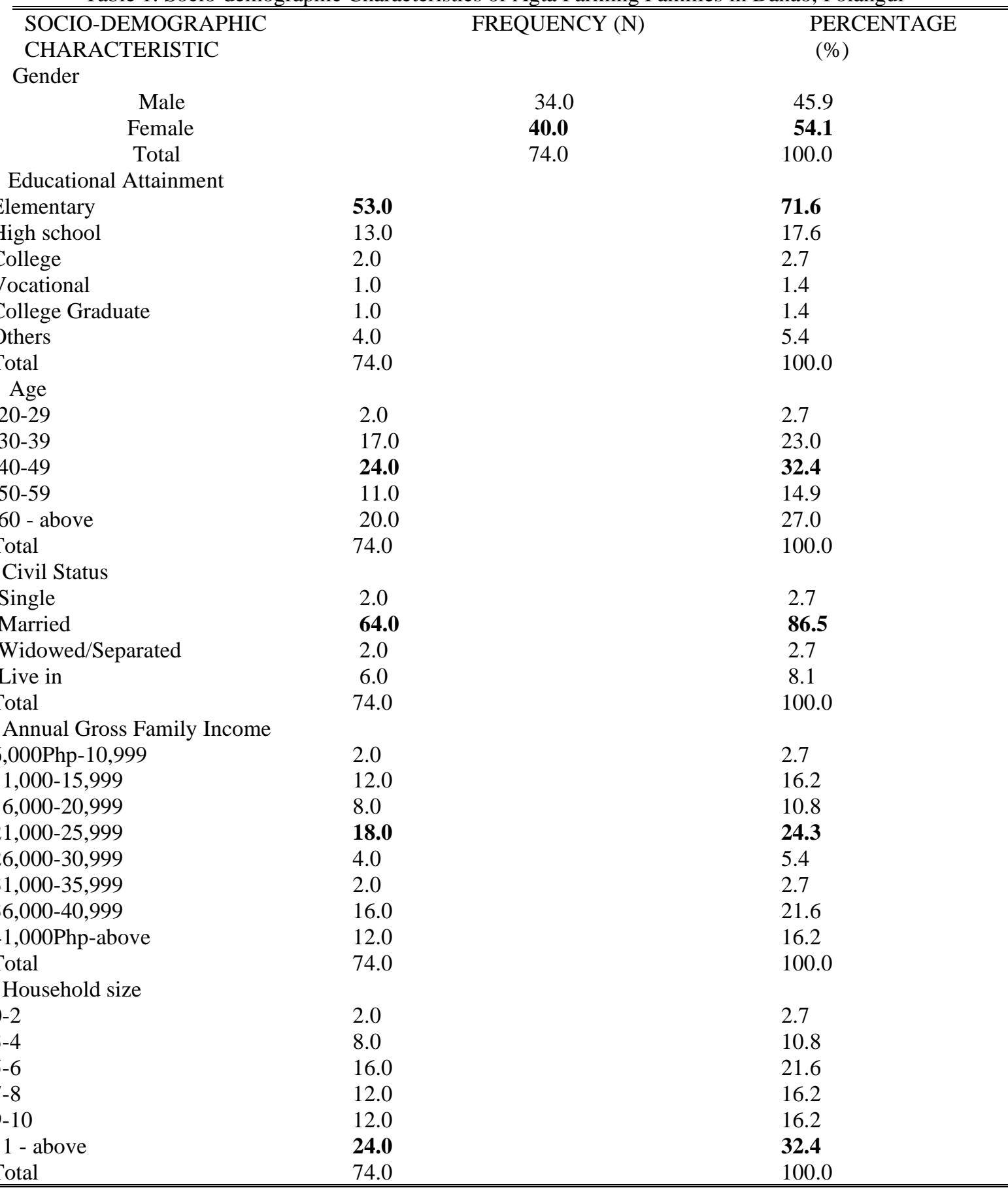

\subsection{FAMILY DYNAMICS OF AGTA FARMING FAMILIES}

\subsubsection{Level of Family Cohesion of Agta Farming Families}

Based on Table 2, data showed that $78.38 \%$ of the Agta farming familiesrespondents had a very connected Balanced Cohesion Level. Family cohesion is defined as the emotional bonding that the family 
have towards one another (Olson, 2011b). A balanced cohesion level, based on the FACES IV tool, is having just the mid-range of connection: not that low nor high. The data reflected that the Agta farming families in the community have a very high connection among family members. According to Olson (2011b), a balanced level of cohesion is the most conducive to healthy family functioning; conversely, having an unbalanced level of cohesion (very high or very low levels) in a family system is associated with problematic family functioning. Having a very connected cohesion level is therefore considered to be unbalanced, as it is stated above that anything with a very high or very low level is associated to disrupted harmonious family system. Based on observation, they are very connected as it can be seen in that they have an extended family structure. Thus, this would create a stronger bond within the family system. According to Jansen (2017), extended family support creates positive interactions among extended family members that lessen the occurrence of negative behaviors such as depression. Agta farming families are family-centered (PhilRice Los Baños, 2016); hence, they give importance to the needs of each member of the family.

Table 2. Balanced Cohesion Level of Agta Farming Families in Barangay Danao, Polangui BALANCED COHESION LEVEL

\begin{tabular}{lll}
\hline Rating & Frequency $(\mathrm{N})$ & Percentage (\%) \\
Somewhat Connected & 0.00 & 0.00 \\
Connected & 16.00 & 21.62 \\
Very Connected & $\mathbf{5 8 . 0 0}$ & $\mathbf{7 8 . 3 8}$ \\
Total & 74.00 & 100.00 \\
\hline \hline
\end{tabular}

As shown in Table 3, majority of the respondents had a disengaged level ranging from very low, low, and moderate, all with $27.03 \%$ each. The disengaged level of cohesion evaluates the degree of participation and engagement among family members (Olson, 2011b). Data presented reflected that the Agta farming families in the community have a relatively low disengagement level among family members. The disengaged level is one of the determinants of the cohesion level; whether it would be balanced or unbalanced. Having a very low, low, and moderate level shows that there is an unbalanced level of cohesion within the family system. Hence, it is a factor that can result to problematic family functioning. This is validated by the data in Table 2 that shows very high level of connectedness. The Agta farming families have close family ties, and they tend to have a better understanding of each other since they are already used to each other's presence and need each other to function as a farming family. 


\begin{tabular}{lll}
\hline \hline DISENGAGED LEVEL & & \\
\hline Rating & Frequency (N) & Percentage (\%) \\
Very Low & $\mathbf{2 0 . 0 0}$ & $\mathbf{2 7 . 0 3}$ \\
Low & $\mathbf{2 0 . 0 0}$ & $\mathbf{2 7 . 0 3}$ \\
Moderate & $\mathbf{2 0 . 0 0}$ & $\mathbf{2 7 . 0 3}$ \\
High & 9.00 & 12.16 \\
Very High & 5.00 & 6.76 \\
Total & 74.00 & 100.00 \\
\hline \hline
\end{tabular}

In terms of Enmeshed level, Table 4 shows that $33.78 \%$ of the respondents had a very high enmeshed level. An enmeshed family has a strongly knitted bond and usually they are the ones who tend to be conforming. Data presented reflected that Agta farming families in the community had a moderate to very strongly knitted relationship among family members. The enmeshed level is another determinant of the cohesion level; whether it would be balanced or unbalanced. There is only a minimal gap to the number of respondents who have a high to very high enmeshed level. Considering most of the respondents, having a very high enmeshed level show that there is an unbalanced level of cohesion within the family system, which may result to a problematic family functioning. Based on observations, Agta farming families have a very high enmeshed level due also to the strong bond that they have among family members. Having an intensified level of connectedness is also not considered to be healthy in a family system because it may influence uniformity to decisions made in the family.

Table 4. Enmeshed Level of Agta Farming Families in Barangay Danao, Polangui

\begin{tabular}{lll}
\hline \hline ENMESHED LEVEL & & \\
\hline Rating & Frequency $(\mathrm{N})$ & Percentage (\%) \\
Very Low & 1.00 & 1.35 \\
Low & 8.00 & 10.81 \\
Moderate & 24.00 & 32.43 \\
High & 16.00 & 21.62 \\
Very High & $\mathbf{2 5 . 0 0}$ & $\mathbf{3 3 . 7 8}$ \\
Total & 74.00 & 100.00 \\
\hline \hline
\end{tabular}




\subsubsection{Level of Family Adaptability of Agta Farming Families}

In terms of the Balanced Flexibility Level, Table 5 shows that $77.03 \%$ of the respondents were very flexible. According to Olson (2011b) family flexibility is the quality and expression of leadership and organization, role relationship, and relationship rules and negotiations within the family system. Data presented reflected that the Agta farming families in the community have a very flexible relationship among family members. A balanced level of flexibility is shown to be the most conducive to healthy family functioning. On the other hand, unbalanced level of flexibility (very high or very low levels) is associated with problematic family functioning (Olson, 2011b). Having a very flexible degree shows that there is an unbalanced flexibility level within the family system. Thus, this may result to disrupted harmonious family relationship among family members. Agta farming families are very flexible based on the data result. In this case, the high flexibility can be seen if there has been a high degree of influence formed that created a positive impact to them. The Agtas are known to be traditional in a sense that they still consider their culture and norms important. But with continuous influential strategies that were being used by them, they learned to easily accept new things and changes that were being introduced within the community so that the family can survive.

\begin{tabular}{lll} 
Table 5. Balanced Flexibility Level of Agta Farming Families in Barangay Danao, Polangui \\
\hline \multicolumn{3}{l}{ BALANCED FLEXIBILITY LEVEL } \\
\hline Rating & Frequency (N) & Percentage (\%) \\
Somewhat Flexible & 0.00 & 0.00 \\
Flexible & 17.00 & 22.97 \\
Very Flexible & $\mathbf{5 7 . 0 0}$ & $\mathbf{7 7 . 0 3}$ \\
Total & 74.00 & 100.00 \\
\hline
\end{tabular}

By level of rigidity, Table 6 shows that majority of Agta Farming Families respondents had a high rigid level with $45.95 \%$. Results of the data showed that majority of the Agta farming families in the community had an established and firm relationship among family members. The Agtas in the community were living together for the longest time in an area that is far from the civilization. They strictly follow their cultural norms and values, thus, when there are new things and sudden change introduced to them, it will be evaluated first, whether it will cause no harm to them and will benefit the majority. It also applies within the family system. Before each member finally concludes to accept a certain idea or thing, it will be first evaluated. Having then perceived that this idea or thing is highly beneficial, they will eventually embrace the change. 
Table 6. Rigid Level of Agta Farming Families in Barangay Danao, Polangui RIGID LEVEL

\begin{tabular}{lll}
\hline Rating & Frequency $(\mathrm{N})$ & Percentage $(\%)$ \\
Very Low & 0.00 & 0.00 \\
Low & 5.00 & 6.76 \\
Moderate & 7.00 & 9.46 \\
High & $\mathbf{3 4 . 0 0}$ & $\mathbf{4 5 . 9 5}$ \\
Very High & 28.00 & 37.84 \\
Total & 74.00 & 100.00 \\
\hline \hline
\end{tabular}

In terms of chaotic level, based on Table $7,85.14 \%$ of the respondents had a very low chaotic level. A chaotic family tends to have no harmony, thus, resulting to a disorganized family system. Data presented showed a relatively low chaotic level which reflected a unified and harmonious relationship between family members. A chaotic family tends to result to a dysfunctional family which may greatly affect each family member, especially the children. In this case, it shows that chaos is not present in Agta farming families. This reflects those problems within the family are less occurring, thus, considered to be positive. The relationship among family members is harmonious and this creates less stress to the family system.

\begin{tabular}{lll}
\multicolumn{3}{l}{ Table 7. Chaotic Level of Agta Farming Families in Barangay Danao, Polangui } \\
\hline \multicolumn{2}{l}{ CHAOTIC LEVEL } \\
\hline Rating & Frequency (N) & Percentage (\%) \\
Very Low & $\mathbf{6 3 . 0 0}$ & $\mathbf{8 5 . 1 4}$ \\
Low & 6.00 & 8.11 \\
Moderate & 3.00 & 4.05 \\
High & 2.00 & 2.70 \\
Very High & 0.00 & 0.00 \\
Total & 74.00 & 100.00 \\
\hline
\end{tabular}

\subsubsection{Level of Family Communication of Agta Farming Families}

By the level of communication, Table 8 shows that $62.16 \%$ of the respondents had a very high communication level among family members, According to Barnesand Olson (1985), family communication is defined as the act of making information, ideas, thoughts, and feelings known among 
family members. It can range from poor to very effective. In addition, communication is generally considered as one of the most vital facets of interpersonal relationships within the family system. Results of the data reflected that Agta farming families had open communication between family members. According to the study conducted by Barnes and Olson (1985), their hypothesis considered that (i) family communication will have a positive relationship to balanced family systems and negative relationship with unbalanced family systems. More specifically: balanced family systems will have significantly better family communication than unbalanced family systems and (ii) family communication will have a positive relationship to family satisfaction. Agta faming family's level of communication tends to be very high. In relation to family systems, the hypothesis (i) has not been proven. There was unbalanced cohesion and unbalanced flexibility levels within the family system of Agta farming families. The intensity of the two components were too high, thus, leading to the unbalanced level. Communication is an important indicator whether a family system will function harmoniously or not. It is a key to all successful relationships. In this case, the data shows that the level of cohesion and flexibility is not that highly dependent on communication. In definition, communication is making known or expressing one's thoughts and feelings, this also includes the transfer of information, ideas, and thoughts. With these stated, it does not generally mean that once there is a high level of communication, there will also be a high level of acceptance that leads to adaptability. The assumption stated based on the data is contrary to the study made by Olson, Russell, and Sprenkle (1983). They hypothesized that effective communication facilitates movement to, and maintenance of systems at the desired (balanced) level of adaptability and cohesion. Therefore, there could be other factors that should still be taken into consideration.

Table 8. Family Communication Level of Agta Farming Families in Barangay Danao, Polangui FAMILY COMMUNICATION LEVEL

\begin{tabular}{lll}
\hline Rating & Frequency $(\mathrm{N})$ & Percentage $(\%)$ \\
Very Low & 0.00 & 0.00 \\
Low & 0.00 & 0.00 \\
Moderate & 0.00 & 0.00 \\
High & 28.00 & 37.84 \\
Very High & $\mathbf{4 6 . 0 0}$ & $\mathbf{6 2 . 1 6}$ \\
Total & 74.00 & 100.00 \\
\hline \hline
\end{tabular}




\subsubsection{Level of Family Satisfaction of Agta Farming Families}

As shown in Table 9, family satisfaction level was very high with $68.92 \%$. According to Olson and Wilson $(1982,1989)$, family satisfaction is defined as the degree to which family members feel happy and fulfilled with each other. The operational definition of family satisfaction includes the three (3) dimensions which are related to the Circumplex Model, namely, the cohesion, flexibility, and communication. Findings from the study showed that Agta Farming Families had a highly satisfactory relationship among family members. According to the study conducted by Olson and Wilson (1982, 1989), their hypothesis considered that (i) families that have high scores on balanced cohesion and balanced flexibility will have higher levels of family satisfaction. Conversely, families with high scores on the unbalanced scales will have lower levels of family satisfaction. More specifically: Balanced families will have significantly higher family satisfaction than Unbalanced families; and (ii) family satisfaction will have a positive relationship to family communication. Based on the result of the data, the hypothesis (i) was disproven due to unbalanced level of cohesion and flexibility. On the other hand, hypothesis (ii) has been proven based on the result. It was indicated from the previous result that there was a high level of communication which then results to a high level of satisfaction. Agtas tend to have a high level of family satisfaction. They see contentment and enjoyment in just the presence of each other. Considering that they are living together with their family, they tend to find happiness within and among themselves. They are seen to be contented with what they have if it helps and sustain their needs and of their families.

Table 9. Family Satisfaction Level of Agta Farming Families in Barangay Danao, Polangui FAMILY SATISFACTION LEVEL

\begin{tabular}{lll}
\hline Rating & Frequency $(\mathrm{N})$ & Percentage (\%) \\
Very Low & 0.00 & 0.00 \\
Low & 0.00 & 0.00 \\
Moderate & 2.00 & 2.70 \\
High & 21.00 & 28.38 \\
Very High & $\mathbf{5 1 . 0 0}$ & $\mathbf{6 8 . 9 2}$ \\
Total & 74.00 & 100.00 \\
\hline \hline
\end{tabular}




\subsection{ENGAGEMENT OF AGTA FARMING FAMILIES TO THE PALAYAMANAN SYSTEM}

\section{APPROACH}

Data reveals that $77.00 \%$ of the respondents from Agta farming families answered that they engaged in PSA. In terms of longevity, majority of the respondents were engaging for about 11-20 years. The respondents considered their basic knowledge on diversified rice-based farming as part of what PSA is all about when it was explained to them what the concept is all about. Thus, their years of engagement based on the data were already long, even though the whole concept for the approach was just formalized in the early 2000s.

Table 10. Engagement and Length of Engagement (years) of Agta Farming Families to PSA

\begin{tabular}{lll}
\hline \hline THE PALAYAMANAN SYSTEM APPROACH & FREQUENCY (N) & PERCENTAGE (\%) \\
\hline Engaging to PSA & $\mathbf{5 7 . 0}$ & $\mathbf{7 7 . 0}$ \\
Yes & 17.0 & 23.0 \\
No & 74.00 & 100.0 \\
Total & & \\
Length of engagement to PSA (years) & 11.0 & 19.3 \\
$1-10$ & $\mathbf{1 8 . 0}$ & $\mathbf{3 1 . 6}$ \\
$\mathbf{1 1 - 2 0}$ & 16.0 & 28.1 \\
$21-30$ & 8.0 & 14.0 \\
$31-40$ & 2.0 & 3.5 \\
$41-50$ & 2.0 & 3.5 \\
No answer & 57.0 & 100.0 \\
Total & & \\
\hline \hline
\end{tabular}

\subsection{SOCIO-DEMOGRAPHIC CHARACTERISTICS, FAMILY DYNAMICS, AND FARM DECISION-} MAKING ON ENGAGEMENT IN PALAYAMANAN SYSTEM APPROACH AND ADAPTATION OF AGRICULTURAL TECHNOLOGIES

The relationship between the socio-demographic characteristics, family dynamics, and farm decision-making on engagement in Palayamanan System Approach and adaptation of agricultural technologies among Agta farming families showed varying results per variable. 


\subsection{AGE AND FAMILY DYNAMICS}

A very weak $(\mathrm{Rs}=0.03-0.15)$ association between age and family dynamics was also revealed using Spearman's rho (Table 11). This means that age is not highly dependent on family dynamics and it does not fully affect the four components of family dynamics.

Table 11. Socio-demographic characteristic (Age) - Family Dynamics Relationship

\begin{tabular}{llc}
\hline \hline SOCIO-DEMOGRAPHIC & SPEARMAN'S RHO VALUE & ASSOCIATION \\
CHARACTERISTIC-FAMILY DYNAMICS & & \\
\hline Age - Family Cohesion & 0.03 & Very Weak \\
Age - Family Flexibility & 0.07 & Very Weak \\
Age - Family Communication & $\mathbf{0 . 1 5}$ & Very Weak \\
Age - Family Satisfaction & 0.02 & Very Weak \\
\hline \hline
\end{tabular}

\subsection{AGE AND FARM DECISION-MAKING IN THE ENGAGEMENT TO PSA AND} AGRICULTURAL TECHNOLOGY ADAPTATION

With the use of Pbis correlation for the age and decision making on the engagement to PSA and agricultural technology adaptation it shows (Table 12$)$ that there is a weak $($ Coef. $=0.18)$ and a negatively weak (Coef. $=-0.33)$ correlation, respectively. Thus, we can say that age is not highly dependent on the decisions made by the respondents on whether to adapt or not to adapt a certain approach and technology. In the community, adaptation is considered as long as the approach or technology is perceived to beneficial to them in such ways. Therefore, adaptation is possible regardless of age.

Table 12. Socio-demographic characteristic (Age) - Farm Decision-Making in Engagement to PSA and Agricultural Technology Adaptation Relationship

\begin{tabular}{|c|c|c|}
\hline $\begin{array}{l}\text { SOCIO-DEMOGRAPHIC } \\
\text { CHARACTERISTIC-ENGAGEMENT TO } \\
\text { PSA AND AGRICULTURAL } \\
\text { TECHNOLOGY ADAPTATION }\end{array}$ & PBIS COEFFICIENT VALUE & CORRELATION \\
\hline Age - Engagement to PSA & 0.18 & Weak \\
\hline Age - Agricultural Technology Adaptation & -0.33 & Weak (-) \\
\hline
\end{tabular}

\subsection{GENDER AND FAMILY DYNAMICS}

Using Cramer's V, the socio-demographic characteristic based on gender to family dynamics (Table 13) shows a moderate to strong association $(\mathrm{V}=0.29-0.50)$. Gender and family cohesion shows the strongest association among the four components of family dynamics. Majority of the respondents are 
females and based on the results, they form a strong association when it comes to family cohesion. Females are known to be the child bearer. They are usually left at home to take care of the children and do household tasks, thus, they tend to have formed a strong bond within other members of the family. Women in general are expected to adopt the role of a caregiver with more concern on emotional wellbeing whom they take care of (Williams et. al, 2017). On the other hand, males are seen to be more highly active in roles such as providing the needs of the family (Eagly and Woods, 2016), therefore, they have lesser time interacting with other members of the family compared to the female.

Table 13. Socio-demographic characteristic (Gender) - Family Dynamics Relationship

\begin{tabular}{lll}
\hline \hline GENDER-FAMILY DYNAMICS & CRAMER'S V VALUE & ASSOCIATION \\
\hline Gender - Family Cohesion & $\mathbf{0 . 5 0}$ & Strong \\
Gender - Family Flexibility & 0.45 & Strong \\
Gender - Family Communication & 0.29 & Moderate \\
Gender - Family Satisfaction & 0.31 & Moderate \\
\hline \hline
\end{tabular}

\subsubsection{Gender and Farm Decision-making in the Engagement to PSA and Agricultural Technology}

\section{Adaptation}

On the other hand, gender shows a moderate association $(\mathrm{V}=0.24)$ to family decision making in engagement to PSA and a weak association $(\mathrm{V}=0.20)$ to agricultural technology adaptation (Table 14). With females as majority of the respondents, it shows that they still have a role in the farm-decision making as they are also still involved in activities done in their farm. But on the other hand, their influence in the decision making on whether to adapt a technology or not is shown to be weak. Still, it is the males who take the full control over the farm and make the most of the farm-decision making. According to Koirala, Mishra, and Mohanty (2015), females are less efficient in farming, but they are adoptive to new things introduced to them, such as improved seed varieties. In addition, females are considered to be better at controlling farming costs. Thus, it could be seen that females as decision makers plays a positive role in supporting the males in farm decisions made.

Table 14. Socio-demographic characteristic (Gender) - Farm Decision-Making in Engagement to PSA and Agricultural Technology Adaptation Relationship

\begin{tabular}{lll}
\hline \hline SOCIO-DEMOGRAPHIC CHARACTERISTIC- & CRAMER'S V VALUE & ASSOCIATION \\
ENGAGEMENT TO PSA AND AGRICULTURAL & & \\
TECHNOLOGY ADAPTATION & & Moderate \\
\hline Gender - Engagement to PSA & 0.24 & Weak \\
Gender - Agricultural Technology Adaptation & 0.20 & \\
\hline \hline
\end{tabular}




\subsubsection{Educational Attainment and Family Dynamics}

Data also shows (Table 15) that educational attainment has a moderate to strong association to family dynamics $(\mathrm{V}=023-0.34)$. The higher the educational attainment gain, the greater magnitude of the association which can be seen in the four components of the family dynamics of Agta farming families especially in their capability to be flexible which can help them in adapting to changes through their gained knowledge and skills in their trainings and formal schooling. According to Solano et al. (2001), there are different factors that can affect the decision-making of farming families, which includes the educational level that influences the decision-making approaches. Having considered the level of educational attainment would help determine if farming families are really open to change. High level of educational attainment would mean that entry of change for adaptation is possible to occur.

Table 15. Socio-demographic characteristic (Educational Attainment) - Family Dynamics Relationship

\begin{tabular}{llll}
\hline SOCIO-DEMOGRAPHIC & CHARACTERISTIC- & CRAMER'S V VALUE & ASSOCIATION \\
FAMILY DYNAMICS & & &
\end{tabular}

\begin{tabular}{lcc}
\hline Educational Attainment - Family Cohesion & 0.29 & Moderate \\
Educational Attainment - Family Flexibility & $\mathbf{0 . 3 4}$ & Strong \\
Educational Attainment - Family Communication & 0.26 & Moderate \\
Educational Attainment - Family Satisfaction & 0.23 & Moderate \\
\hline \hline
\end{tabular}

\subsubsection{Educational Attainment and Farm Decision-making in the Engagement to PSA and} Agricultural Technology Adaptation

Moreover, in terms of educational attainment it shows (Table 16) a strong $(\mathrm{V}=0.33)$ and moderate $(\mathrm{V}=0.15)$ association to the decision of the family to engage in PSA and adapt agricultural technology, respectively. The results show that there is an increase in the magnitude of association per decisions made in adapting. As said earlier, formal schooling could create an impact in molding and influencing one's perspective through knowledge and skills gained. Thus, the more they know, the more open they become to embrace new things and changes that are being introduced to them although it is lesser for agricultural technology adaptation maybe due to financial limitations.

Table 16. Socio-demographic characteristic (Educational Attainment) - Farm Decision-Making in Engagement to PSA and Agricultural Technology Adaptation Relationship

\begin{tabular}{llllll}
\hline \hline SOCIO-DEMOGRAPHIC & CHARACTERISTIC- & CRAMER'S & V & ASSOCIATION \\
ENGAGEMENT TO PSA & AND & AGRICULTURAL & VALUE & & \\
TECHNOLOGY ADAPTATION & & & & &
\end{tabular}




\subsubsection{Family Income and Family Dynamics}

A negatively very weak ( $R s=-0.02--0.10)$ association between family income and family dynamics was also revealed using Spearman's rho (Table 17). This shows that there is a very low magnitude of association between the two variables. Thus, family income would not greatly affect their current state of dynamics within the family. Agta farming families, based on the results of the study, have a shown a high level of satisfaction. Thus, they find enjoyment and contentment in simple ways and with just what they have. Money does not fully affect their level of satisfaction since they greatly consider the good and harmonious relationship that is built and maintained in the family in order to survive.

Table 17. Socio-demographic characteristic (Family Income) - Family Dynamics Relationship

\begin{tabular}{llr}
\hline \hline SOCIO-DEMOGRAPHIC & SPEARMAN'S RHO VALUE & ASSOCIATION \\
CHARACTERISTIC-FAMILY DYNAMICS & & \\
\hline Family Income - Family Cohesion & -0.02 & Very Weak (-) \\
Family Income - Family Flexibility & $\mathbf{- 0 . 1 0}$ & Very Weak (-) \\
Family Income - Family Communication & -0.06 & Very Weak (-) \\
Family Income - Family Satisfaction & -0.03 & Very Weak (-)
\end{tabular}

\subsubsection{Family Income and Farm Decision-making in the Engagement to PSA and Agricultural} Technology Adaptation

In addition, family income and decision making on the engagement to PSA and agricultural technology adaptation shows (Table 18) a very weak (Coef. $=0.09$ and 0.04 ) correlation, respectively. Therefore, regardless of how high they earn, it does not greatly affect their decision to adapt. This may be due to the reason that they have been used to their current lifestyle, hence, it is not that influential as a factor. Also considering the fact that they still remain to be traditional, they tend to rely on what they just currently have and been using for the longest time.

Table 18. Socio-demographic characteristic (Family Income) - Farm Decision-Making in Engagement to PSA and Agricultural Technology Adaptation Relationship

\begin{tabular}{lcclc}
\hline \hline \multicolumn{2}{l}{ SOCIO-DEMOGRAPHIC } & CHARACTERISTIC- & PBIS & CORRELATION \\
ENGAGEMENT & TO & PSA & AND & COEFFICIENT \\
& & & & VALUE
\end{tabular}


AGRICULTURAL ADAPTATION

\begin{tabular}{llll}
\hline \multicolumn{2}{l}{ Family Income - Engagement to PSA } & 0.09 & Very Weak \\
Family Income - Agricultural & Technology & 0.04 & Very Weak \\
Adaptation & & &
\end{tabular}

\subsubsection{Civil Status and Family Dynamics}

The data also shows (Table 19) that there is a moderate association $(\mathrm{V}=0.14-0.2)$ between civil status and family dynamics. Among the four components of family dynamics, family satisfaction shows the highest association with civil status. Majority of the respondents were married couples; thus, it reflects that there is a gained enjoyment and contentment within their relationship. According to Grover and Helliwell (2017), still, married couples are more satisfied, suggesting a casual effect at all stages of the marriage, from the pre-nuptial bliss to marriages of long duration. Moreover, higher level of satisfaction from married couples could be due to different aspects like the presence of emotional support and social security within each other.

Table 19. Socio-demographic characteristic (Civil Status) - Family Dynamics Relationship

\begin{tabular}{llc}
\hline \hline SOCIO-DEMOGRAPHIC & CRAMER'S V VALUE & ASSOCIATION \\
CHARACTERISTIC-FAMILY DYNAMICS & & Moderate \\
\hline Civil Status - Family Cohesion & 0.15 & Moderate \\
Civil Status - Family Flexibility & 0.14 & Moderate \\
Civil Status - Family Communication & 0.14 & Moderate \\
Civil Status - Family Satisfaction & $\mathbf{0 . 2 0}$ &
\end{tabular}

\subsubsection{Civil Status and Farm Decision-making in the Engagement to PSA and Agricultural Technology Adaptation}

There has been a same trend using Pbis correlation for the civil status and decision making on the engagement to PSA and agricultural technology adaptation with both moderate (Coef. $=0.13-0.22$ ) correlations (Table 20). Civil status can be seen to be dependent to farm decision-making. Based on the result of the survey conducted, it showed that most of the farm decisions were made jointly. Hence, we can say that couples who are married tend to have a balance of role in making the decisions in the farm. In addition, they support and help each other in different aspects of their family life. 
Table 20. Socio-demographic characteristic (Civil Status) - Farm Decision-Making in Engagement to PSA and Agricultural Technology Adaptation Relationship

\begin{tabular}{|c|c|c|}
\hline $\begin{array}{l}\text { SOCIO-DEMOGRAPHIC } \quad \text { CHARACTERISTIC- } \\
\end{array}$ & PBIS COEFFICIENT & CORRELATION \\
\hline $\begin{array}{l}\text { ENGAGEMENT TO PSA AND AGRICULTURAL } \\
\text { TECHNOLOGY ADAPTATION }\end{array}$ & VALUE & \\
\hline Civil Status - Engagement to PSA & 0.22 & Moderate \\
\hline Civil Status - Agricultural Technology Adaptation & 0.13 & Moderate \\
\hline
\end{tabular}

\subsubsection{Household size and Family Dynamics}

Moreover, a very weak $(\mathrm{Rs}=0.01-0.13)$ association between household size and family dynamics was also revealed using Spearman's rho (Table 21). Thus, it reflects that the four components of family dynamics is not highly dependent on the household size. With a result of a very weak magnitude of association, the number of the people composing a family would not greatly create an impact to the dynamics of the family.

Table 21. Socio-demographic characteristic (Household size) - Family Dynamics Relationship.

\begin{tabular}{llc}
\hline SOCIO-DEMOGRAPHIC & SPEARMAN'S RHO VALUE & ASSOCIATION \\
CHARACTERISTIC-FAMILY DYNAMICS & & \\
\hline Household size - Family Cohesion & 0.07 & Very Weak \\
Household size - Family Flexibility & 0.08 & Very Weak \\
Household size - Family Communication & $\mathbf{0 . 1 3}$ & Very Weak \\
Household size - Family Satisfaction & 0.01 & Very Weak
\end{tabular}

\subsubsection{Household size and Farm Decision-making in the Engagement to PSA and Agricultural}

\section{Technology Adaptation}

There was a same trend using Pbis correlation for the household size and decision making on the engagement to PSA and agricultural technology adaptation both with very weak (Coef. $=0.09$ and 0.04$)$ correlations (Table 22). Thus, farm decisions made are not highly dependent on household size.

Table 22. Socio-demographic characteristic (Household size) - Farm Decision-Making in Engagement to PSA and Agricultural Technology Adaptation Relationship

\begin{tabular}{lllll}
\hline \hline SOCIO-DEMOGRAPHIC & CHARACTERISTIC- & PBIS COEFFICIENT & CORRELATION \\
ENGAGEMENT TO PSA AND & AGRICULTURAL & VALUE \\
TECHNOLOGY ADAPTATION & & & \\
\end{tabular}

\begin{tabular}{lcc}
\hline Household size - Engagement to PSA & 0.09 & Very Weak \\
Household size - Agricultural Technology Adaptation & 0.04 & Very Weak
\end{tabular}




\subsubsection{Family Dynamics and Farm Decision-making in the Engagement to PSA and Agricultural}

\section{Technology Adaptation}

In terms of the data for the family dynamics in relation to farm decision making in the engagement to PSA and agricultural technology adaptation (Table 23) there are weak associations ( $\mathrm{V}=0.02-0.09)$, except for family cohesion with a moderate correlation to engagement to PSA $(\mathrm{V}=0.13)$. Weak associations can be seen more in the four components of family dynamics to farm decision-making. Thus, we can say that the magnitude of association on whether to adapt the PSA or a certain technology in relation to family dynamics is not that highly intense. But one component of family dynamics made an exemption. Family cohesion, as defined as the emotional bonding that family members have toward one another, could influence a certain decision on the engagement to PSA. Based on the family systems theory, it states that a family works and functions as a system to attain a certain goal. In relation to this, a strong bond should be created within the family in order to function well. In the PSA, members of the family are highly suggested to be involved since it includes lots of manual labor and maintenance in the farm. Thus, creating a strong emotional bond could help lead to involvement of each member in engaging to PSA. The family is considered to be a system; therefore, there are certain roles to be played by each member for them to acquire a certain goal. In this case, the goal is to sustain the food consumption supply of the family and help increase their means of income.

Table 23. Family Dynamics - Farm Decision-Making in Engagement to PSA and Agricultural Technology Adaptation Relationship

\begin{tabular}{|c|c|c|}
\hline $\begin{array}{lccc}\text { FAMILY DYNAMICS-ENGAGEMENT } & \text { TO } & \text { PSA } & \text { AND } \\
\text { AGRICULTURAL TECHNOLOGY ADAPTATION } & \end{array}$ & $\begin{array}{l}\text { CRAMER'S V } \\
\text { VALUE }\end{array}$ & ASSOCIATION \\
\hline Family Cohesion - Engagement to PSA & 0.13 & Moderate \\
\hline Family Cohesion - Agricultural Technology Adaptation & 0.06 & Weak \\
\hline Family Flexibility - Engagement to PSA & 0.03 & Weak \\
\hline Family Flexibility - Agricultural Technology Adaptation & 0.08 & Weak \\
\hline Family Communication - Engagement to PSA & 0.02 & Weak \\
\hline Family Communication - Agricultural Technology Adaptation & 0.03 & Weak \\
\hline Family Satisfaction - Engagement to PSA & 0.09 & Weak \\
\hline Family Satisfaction - Agricultural Technology Adaptation & 0.05 & Weak \\
\hline
\end{tabular}

\section{SUMMARY AND CONCLUSION}

There will be some instances that it will be difficult to introduce new things to the Agta IP farming families as they have a traditional and closed family system - due to demographic and cultural aspects, 
which affects their perspectives in life. This can be seen as a challenge but should not limit effective development interventions such as trainings and seminars and introduction and provision of agricultural technologies to help them. Further, studies on IP communities in the Philippines are limited. Thus, exploring their family dynamics would be an entry point to know and understand the IPs for further formulation of strategies that will help improve and enhance their present lives, especially in encouraging them to continuously engage in the Palayamanan System Approach.

\section{RECOMMENDATIONS}

Conduct of more studies involving other ethnic groups of IPs is recommended to widely understand their current ways of life and assess their needs, especially in terms of sustaining the basic needs of their families and means of income generation. Moreover, evaluating first whether these people are really in need of development interventions should be considered. As reflected in the study, Agta farming families tends to have a high level of satisfaction. This only shows that they are happy and content within their family if they are together and have a sufficient supply of their basic needs. Continuous provision of assistance such as training, seminars, and monitoring will greatly help in widening their perspective as they adapt to changes for them to survive. It can also be noteworthy to explore the IP's family dynamics and engagement level to adaptation of technologies should there be extreme events such as climate change, severe drought, typhoons, and pandemic. It is indeed challenging for the Agta IPs to be involved in such activities; thus, positive reinforcements could be applied in the process for them to fully devote their time in the development interventions being offered to them. 


\section{REFERENCES}

EAGLY A and WOODS W. 2016. Social Role Theory of Sex Differences. Wiley Online Library. Retrieved from https://doi.org/10.1002/9781118663219.wbegss183.

GROVER S and HELLIWELL J. 2017. How's Life at Home? New Evidence on Marriage and the Set Point for Happiness. Journal of Happiness Studies. Retrieved from https://doi.org/10.1007/s10902-017-9941-3.

KOIRALA K, MISHRA A and MOHANTY S. 2015. The role of Gender in Agricultural Productivity in the Philippines: The Average Treatment Effect. Paper presented at the Southern Agricultural Economics Association's 2015 Annual Meeting, January 31-February 3, 2015, Atlanta, Georgia.

OLSON D, GORALL D and TIESEL J. 2007. FACES IV and the Circumplex Model: Validation Study. Minneapolis, MN.: Life Innovations, Inc.

OLSON D. 2011. FACES IV Circumplex Model: Validation Study. Minneapolis, MN.: Life Innovations, Inc.

OLSON D. 2011A. Circumplex Model of Marital \& Family Systems. Minneapolis, MN.: Life Innovations, Inc.

NGUYEN TP, SEDDAIU G, VIRDIS SG, TIDORE C, PASQUI M, ROGGERO

PP. 2016. Perceiving to learn or learning to perceive? Understanding farmers' perceptions and adaptation to climate uncertainties. Agricultural Systems, 143:205-216.

PHILIPPINE RICE RESEARCH INSTITUTE LOS BAÑOS. 2015. Anthropological and Socio-economic Characterization of Bicol's Agta Indigenous Peoples: Phase 1 of Enhancing the Capabilities of Bicol's Agta IPs through Palayamanan Approach. Terminal Report 2012-2014. Los Baños, Philippines.

PHILIPPINE RICE RESEARCH INSTITUTE LOS BAÑOS. 2016. Anthropological and Socioeconomic Characterization of Selected Indigenous Farming Communities in the Bicol Region: Nagtatalubong Danao (Growing Danao). 3:1-86.

PHILIPPINE STATISTICS AUTHORITY. 2015. Per capita poverty threshold, poverty incidence and magnitude of poor families, by region and province. Retrieved from: http://www.openstat.psa.gov.ph/dataset/poverty/resource.

SOLANO C, LEON H, PEREZ E and HERRERO, M. 2001. Who makes farming decisions? A study of Costa Rican dairy farmers. Agricultural Systems, 67(3):181-199.

STRONG BOND. 2009. Understanding Families: Family Dynamics. Retrieved from http://www.strongbonds.jss.org.au/workers/families/familydynamics.pdf.

WILLIAMS L, GIDDINGS L, BELLAMY G and GOTT M. 2017. Because it's the wife who had to look after the man: A descriptive qualitative study of older woman and the intersection of gender and provision of family care giving at the end of life. PalliatMed.31(3):223-230. 